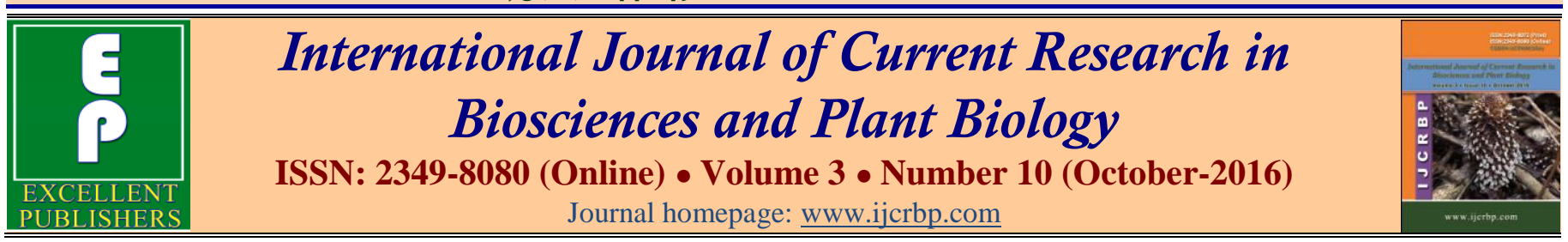

\title{
Anti-inflammatory Activity of Traditionally Important Insulin Plant Costus Species for the Treatment of Inflammation in Human
}

\author{
M. Ferosekhan', A. Ramu ${ }^{*}$ and S. Ravikumar ${ }^{2}$ \\ ${ }^{1}$ Department of Chemistry, Madurai Kamaraj University, Madurai - 625 021, Tamil Nadu, India \\ ${ }^{2}$ Department of Oceanography and Coastal Area Studies, Alagappa University, Thondi Campus, Thondi - 623 409, \\ Tamil Nadu, India \\ *Corresponding author.
}

\begin{abstract}
A b s t r a c t
Fresh elder leaves of species viz., Costus pictus and Costus speciosus were collected from Western Ghats, Tamil Nadu. Leaves were washed thrice in sterile distilled water and shade dried and powdered. Then 500g of powdered leaves was soaked in 1 litre of ethanol water mixture (3:1) for 10 days in an air tight clean glass container. Mixing was done every day so as to enable to enhance the maximum extraction of bioactive compounds. After that, the solvent containing bioactive extracts were filtered through muslin cloth and kept in the rotary flash evaporator (with solvent trap) so as to obtain solvent free extract residue and tested for in vitro assessment of anti-inflammatory property. Leaf extract of $C$. pictus and $C$. speciosus at different concentrations provided significant protection against denaturation of proteins. The $C$. pictus extract showed maximum percentage inhibition of $97.87 \%$ at $400 \mathrm{mg} / \mathrm{ml}$, whereas $C$. speciosus gave $86.04 \%$ at $400 \mathrm{mg} / \mathrm{ml}$. Diclofenac sodium, a standard anti-inflammatory drug showed the maximum inhibition $97.56 \%$ at the concentration of $400 \mathrm{mg} / \mathrm{ml}$. So it can be concluded from the present study that, the $C$. pictus and $C$. speciosus leaf extract can be used as an anti-inflammatory agent.
\end{abstract}

\author{
Article Info \\ Accepted: 23 September 2016 \\ Available Online: 06 October 2016
}

\section{Ke ywords}

Anti-inflammatory

Bio-active compounds

Costus species

Insulin plants

Phytochemicals

Traditional medicinal plants

\section{Introduction}

Medicinal plants with anti-inflammatory activities are considerably employed in the traditional treatment of several disorders of inflammation. The inflammatory response involved a complex assay of enzyme activation, mediator release, fluid extravasations, cell migration, tissue breakdown and repair (Vane and Bolding, 1995) which are aimed at host defense and usually activated in most disease conditions. These different reactions in the inflammatory response cascade are therapeutic targets that anti-inflammatory agents including medicinal plants interfere with to suppress exacerbated inflammatory responses usually involved in such disorders as rheumatoid arthritis, infection or injury. Inhibition of the synthesis of pro-inflammatory prostaglandins is one of such therapeutic targets to which some of the potent antiinflammatory agents of clinical relevance (eg. NSAIDs) owe their activity (Flower and Vane, 1974). Several anti-inflammatory medicinal plants have also demonstrated the ability to inhibit the synthesis of prostaglandins (McGaw et al., 1998). Terrestrial plants have long been used traditionally to inhibit inflammation and pain mostly contains triterpenes tile sesquiterpenes lacton and parthenolide which inhibit expression of Cox2 , while yomogin inhibit NO production by suppressing 
iNos expression and/or activity. On the other hand, polyphenols like theaflavin3, 3-digallate and flavanols inhibit both NO generation and Cox (1 and 2) enzymes (Sautebin, 2000). In recent years, patients with chronic rheumatic disorders are adopting complementary/ alternative medicine (CAM) to help manage their chronic painful conditions. The prevalence of CAM was between the ranges of 33-90\% (Herman et al., 2004). Collectively the evidence demonstrates that, some CAM modalities show significant promise such as herbal medicine, diets, acupuncture, homeopathy, massage and supplements. Natural products have been an important resource for the maintenance of life for ages. Natural products become increasingly important as a source of pharmacotherapeutics for the treatment of chronic diseases or as raw material from which more or less complex chemical structures with particular biological activity. Due to the uncertainty involved in predicting future pharmacological potential, any selection of bioactive marine natural products is bound to be incomplete. The goal of highlighting compounds that are likely to become clinical candidates is also complicated by the fact that, pharmaceutical companies are naturally reluctant to talk about compounds in the early stages of development. Herbal remedies and alternative medicines are used throughout the world and in the past herbs often represented the original sources of most drugs (Cooper, 2004). The plant kingdom has provided an endless source of medicinal plants first used in their crude forms as herbal teas, syrups, infusions, ointments, liniments and powders (Tsao and Zeltzer, 2005).

Indian subcontinent is a vast repository of medicinal plants that are used in traditional medical treatments (Chopra et al., 1956), which also forms a rich source of knowledge. The various indigenous systems such as siddha, ayurveda, unani and allopathy use several plant species to treat different ailments (Rabe and Staden, 1997). In India around 20,000 medicinal plant species have been recorded (Dev, 1997), but more than 500 traditional communities use about 800 plant species for curing different diseases (Kamboj, 2000). Currently 80 $\%$ of the world population depends on plant-derived medicine for the first line of primary health care for human alleviation because it has no side effects. Plants are important sources of medicines and presently about $25 \%$ of pharmaceutical prescriptions in the United States contain at least one plant-derived ingredient. In the last century, roughly 121 pharmaceutical products were formulated based on the traditional knowledge obtained from various sources (Perumal Samy et al., 2007). The use of medicinal plants in modern medicine used in the world to prevent or to cure diseases. The plant Costus pictus cultivated in uttarkannada of Karnataka in India. In this area people take traditionally 2-3 leaves of this plant twice a day for the management of diabetes. It is prostrate growing plant with spreading rooting stems. Costus speciosus found in various parts of India, Taiwan and Malaysia. It is succulent plant with long simple spirally arranged leaves and spirally twisted stems and has horizontal rhizomes which are used traditionally. The rhizomes are used in constipation, skin diseases, fever, asthma, bronchitis, inflammation and anemia and are medicinally tried to utilize antihelminthic, astringent, purgative and aphrodisiac properties (Warrior, 1994). The alkaloidal function from Costus speciosus was evaluated for anticholinesterase activity and was later demonstrated to possess papaverine like smooth muscle relaxant action, diuretic, cardiotonic and central nervous system depressant activities. It was recognized as a source of diosgenin and the saponin content was found to have antifungal activity (Singh, 1992). Traditionally this rhizome has been used for many inflammatory conditions in fever. Recent works proved that, extracts from insulin species exhibited sensitivity against human, animal and plant pathogens. But no attempt has been taken so far on the medicinal properties of Costus species for the treatment of anti-inflammatory and hence the present study has been undertaken.

\section{Materials and methods}

\section{Collection and extraction of bioactive compounds}

Fresh elder leaves of species viz., Costus pictus and Costus speciosus were collected from Western Ghats, Tamil Nadu. Leaves were washed thrice in sterile distilled water to remove the epiphytes. Samples will be shade dried and powdered. The powdered leaves $(500 \mathrm{~g})$ was soaked in 1 litre of ethanol water mixture (3:1) for 10 days in an air tight clean glass container. Mixing was done every day so as to enable to enhance the maximum extraction of bioactive compounds. After that, the solvent containing bioactive extracts were filtered through muslin cloth and kept in the rotary flash evaporator (with solvent trap) so as to obtain solvent free extract residue and stored in refrigerator for further use. The presence of saponins, tannins, alkaloids, flavonoids, anthraquinones, glycosides and reducing sugars in the extract were tested by following simple and standard qualitative methods earlier described by Trease and Evans (1989) and Sofowora (1993). Triplicates were maintained throughout the experiment to get concordant values and the results were statistically analysed for significance. 
In vitro evaluation of anti-inflammatory activity of chosen extracts

\section{Membrane stabilization property}

Preparation of red blood cells (RBCs) suspension: Fresh whole human blood $(10 \mathrm{ml})$ was collected and transferred to the heparin zed centrifuged tubes. The tubes were centrifuged at $3000 \mathrm{rpm}$ for $10 \mathrm{~min}$ and were washed three times with equal volume of normal saline. The volume of the blood was measured and reconstituted as $10 \% \mathrm{v} / \mathrm{v}$ suspension with normal saline.

\section{Heat induced hemolysis}

The $2 \mathrm{ml}$ reaction mixture is consisted of $1 \mathrm{ml}$ of test extract and $1 \mathrm{ml}$ of $10 \%$ RBCs suspension, instead of drug only saline was added to the control test tube. Aspirin was taken as a standard drug. All the centrifuged tubes containing reaction mixture were incubated in a water bath at $56^{\circ} \mathrm{C}$ for $30 \mathrm{~min}$. At the end of the incubation, the tubes were cooled under running tap water. The reaction mixture was centrifuged at $2500 \mathrm{rpm}$ for $5 \mathrm{~min}$ and the absorbance of the supernatants was taken at $560 \mathrm{~nm}$. The experiment was performed in triplicate. Percent membrane stabilization activity was calculated by the formula mentioned below:

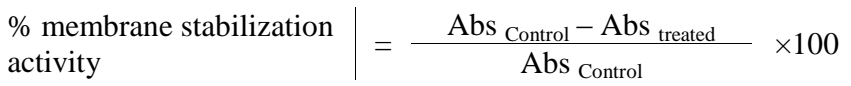

\section{In vitro evaluation of anti-arthritic activity of chosen extracts}

\section{Inhibition of protein denaturation assay}

The reaction mixture $(0.5 \mathrm{ml})$ consisted of $0.45 \mathrm{ml}$ bovine serum albumin (5\% aqueous solution) and $0.05 \mathrm{ml}$ of chosen extract (100 to $400 \mathrm{mg} / \mathrm{ml}$ of final volume) was prepared. $\mathrm{pH}$ was adjusted at 6.3 using a small amount of $1 \mathrm{~N} \mathrm{HCL}$. The samples were incubated at $37^{\circ} \mathrm{C}$ for 30 min. After cooling the samples, $2.5 \mathrm{ml}$ phosphate buffer saline ( $\mathrm{pH}$ 6.3) was added to each tube. Turbidity was measured spectrophotometrically at $660 \mathrm{~nm}$ for control test $0.05 \mathrm{ml}$ distilled water was used instead of extracts while product control test lacked bovine serum albumin. The percentage inhibition of protein denaturation was calculated as follows.

$$
\begin{aligned}
& \% \text { inhibition of } \\
& \text { protein denaturation }
\end{aligned} \mid=\frac{\mathrm{Abs}_{\mathrm{Control}}-\mathrm{Abs}_{\text {treated }}}{\mathrm{Abs} \mathrm{Control}} \times 100
$$

The control represents $100 \%$ protein denaturation. The results were compared with acetyl salicylic acid $(250 \mathrm{mcg} / \mathrm{ml})$ treated samples.

\section{Inhibition of egg albumin denaturation assay}

The $5 \mathrm{ml}$ of reaction mixture was comprised of $0.2 \mathrm{ml}$ of egg's albumin (from hen's egg ), $2.8 \mathrm{ml}$ of phosphate buffered saline (PBS, pH 6.4) and $2 \mathrm{ml}$ of varying concentration of extracts so that final concentrations become 100 to $400 \mathrm{mg} / \mathrm{ml}$. Similar volume of double distilled water served a control. Then the mixture was incubated at $37^{\circ} \mathrm{C}$ in BOD incubator for about $15 \mathrm{mins}$ and then heated at $70^{\circ} \mathrm{C}$ for 5 mins. After cooling, their absorbance was measured at $660 \mathrm{~nm}$ by using pure blank. Diclofenac sodium (standard drug) at the final concentration of (100 to $400 \mathrm{gm} / \mathrm{ml})$ was used as reference drug and treated as such for determination of absorbance (Mizushima and Kobayashi, 1968). The percentage inhibition of protein denaturation was calculated by using the following formula:

$$
\% \text { inhibition }=\frac{\mathrm{Abs}_{\text {Control }}-\mathrm{Abs}_{\text {treated }}}{\mathrm{Abs} \text { Control }} \times 100
$$

\section{Statistical analysis}

The data were expressed as mean \pm standard error mean (SEM). The data were analyzed by using Graph pad software Prismversion5 by one way analysis of variance (ANOVA). The test was followed by Dunnett's t-test, $p$ values less than 0.05 were considered as significance.

\section{Results and discussion}

There are certain problems in using animals in experimental pharmacological research, such as ethical issues and the lack of rationale for their use when other suitable methods are available or could be investigated. Hence, in the present study the protein denaturation bioassay, albumin denaturation and membrane stabilization were selected for in vitro assessment of antiinflammatory property of ethanol extracts of Costus pictus and Costus speciosus leaves.

Protein denaturation is a process in which proteins lose their tertiary structure and secondary structure by application of external stress or compound, such as strong acid or base, a concentrated inorganic salt, an organic solvent or heat. Most biological proteins lose their biological function when denatured. Denaturation of proteins is a well documented cause of inflammation 
(Sangita et al., 2012). Leaf extract of C. pictus and C. speciosus at different concentrations provided significant protection against denaturation of proteins (Table 1). The $C$. pictus extract showed maximum percentage inhibition of $97.87 \%$ at $400 \mathrm{mg} / \mathrm{ml}$, whereas C. speciosus gave $86.04 \%$ at $400 \mathrm{mg} / \mathrm{ml}$. Diclofenac sodium, a standard anti-inflammatory drug showed the maximum inhibition $97.56 \%$ at the concentration of 400 $\mathrm{mg} / \mathrm{ml}$. Most of the investigators have reported that denaturation of protein is one of the cause of inflammation. Production of autoantigens in certain inflammatory diseases may be due to in vivo denaturation of proteins. Mechanism of denaturation probably involves alteration in electrostatic, hydrogen, hydrophobic and disulphide bonding (Deshpande et al., 2009; Kokila et al., 2013; Arya and Vidya, 2013). From the results of present study it can be stated that ethanolic extract of $C$. pictus and $C$. speciosus leaves are capable of controlling the production of autoantigen and inhibits denaturation of protein in inflammatory disease.
Denaturation of proteins is a well documented cause of inflammation. As part of the investigation on the mechanism of the anti inflammation activity, ability of different solvent plant extract protein denaturation was studied. It was effective in inhibiting heat induced albumin denaturation (Table 2). Maximum percentage of inhibition $85.29 \%$ at $400 \mathrm{mg} / \mathrm{ml}$, was observed from ethanol extract of $C$. speciosus followed by $C$. pictus extract (81.35). Diclofenac sodium, a standard antiinflammatory drug showed the maximum inhibition $97.56 \%$ at the concentration of $400 \mathrm{mg} / \mathrm{ml}$. This antidenaturation effect was further supported by the change in viscosities (data not shown). It has been reported that the viscosities of protein solutions increase on denaturation (Anson and Mirsky, 1932). This decrease in viscosities may be due to decrease in concentration of test extract/drug in reaction mixture, which resulted in decreased viscosity; and/or other uncertain physicochemical factors. Nevertheless, the viscosity data indicated inhibition of protein (albumin) denaturation.

Table 1. Protein denaturation assay of Costus species.

\begin{tabular}{|c|c|c|c|}
\hline Name of the plant species & Concentration $\left(\mathrm{mg} \mathrm{ml}^{-1}\right)$ & O.D at $660 \mathrm{~nm}$ & Inhibition (\%) \\
\hline \multirow[t]{4}{*}{ Costus pictus } & 100 & $0.63 \pm 0.4$ & 46.80 \\
\hline & 200 & $0.78 \pm 0.32 *$ & 65.95 \\
\hline & 300 & $0.82 \pm 0.41 * *$ & 74.46 \\
\hline & 400 & $0.93 \pm 0.51 * * *$ & 97.87 \\
\hline \multirow[t]{4}{*}{ Costus speciosus } & 100 & $0.38 \pm 0.22 * *$ & 55.81 \\
\hline & 200 & $0.25 \pm 0.17$ & 70.93 \\
\hline & 300 & $0.17 \pm 0.31 * *$ & 80.23 \\
\hline & 400 & $0.12 \pm 0.5^{* * *}$ & 86.04 \\
\hline Diclofenac sodium (Positive control) & 400 & $0.2 \pm 0.14$ & 97.56 \\
\hline Negative control & 0 & $0.47 \pm 0.25$ & 0 \\
\hline
\end{tabular}

The above data represents the mean \pm SEM (n=6) Significant, ${ }^{*} p<0.05,{ }^{* *} p<0.01,{ }^{* * *} p<0.001$ when compared with Control using One way ANOVA followed by Dunnett's multiple " $\mathrm{t}$ " test.

Table 2. Albumin denaturation assay of Costus species.

\begin{tabular}{|c|c|c|c|}
\hline Extract & Concentration (mg.ml ${ }^{-1}$ ) & O.D at $660 \mathrm{~nm}$ & Percentage inhibition $(\%)$ \\
\hline \multirow[t]{4}{*}{ Costus pictus } & 100 & $0.20 \pm 0.23^{* *}$ & 66.10 \\
\hline & 200 & $0.17 \pm 0.41$ & 71.18 \\
\hline & 300 & $0.14 \pm 0.51 *$ & 76.27 \\
\hline & 400 & $0.11 \pm 2.1 * * *$ & 81.35 \\
\hline \multirow[t]{4}{*}{ Costus speciosus } & 100 & $0.18 \pm 2.1 *$ & 73.52 \\
\hline & 200 & $0.14 \pm 1.8^{*}$ & 79.41 \\
\hline & 300 & $0.12 \pm 0.3$ & 82.35 \\
\hline & 400 & $0.10 \pm 2.2 * * *$ & 85.29 \\
\hline Diclofenac sodium (Positive control) & 400 & 0.2 & 97.56 \\
\hline Negative Control & 0 & 0.59 & 0 \\
\hline
\end{tabular}

The above data represents the mean \pm SEM ( $\mathrm{n}=6)$ Significant, ${ }^{*} p<0.05$, ${ }^{* *} p<0.01,{ }^{*} * * p<0.001$ when compared with Control using One way ANOVA followed by Dunnett's multiple " $t$ " test. 
The HRBC membrane stabilization has been used as a method to study the in vitro anti inflammatory activity because the erythrocyte membrane is analogous to the lysosomal membrane and its stabilization implies that the extract may well stabilize lysosomal membranes. Stabilization of lysosomal is important in limiting the inflammatory response by preventing the release of lysosomal constituents of activated neutrophil, such as bacterial enzymes and proteases, which causes further tissue inflammation and damage upon extra cellular release. The lysosomal enzymes released during inflammation produce a various disorders. The extra cellular activity of these enzymes are said to be related to acute or chronic inflammation. The non steroidal drugs act either by inhibiting these lysosomal enzymes or by stabilizing the lysosomal membrane (Govindappa et al., 2010).

Stabilization of RBCs membrane was studied for further establishes the mechanism of anti-inflammatory action of C. pictus and C. speciosus leaves. Both the extracts were shown inhibiting the heat induced hemolysis compare with standard Diclofenac sodium. These results provide evidence for membrane stabilization as an additional mechanism of their anti inflammatory effect. The extracts inhibited the heat induced hemolysis of RBCs to varying degree as per Table 3 . The maximum inhibitions $88.42 \%$ at $400 \mathrm{mg} / \mathrm{ml}$ was observed from C. speciosus leaf extract followed by $C$. pictus extract $83.33 \%$ and the Diclofenac sodium standard drug showed the maximum inhibition $97.56 \%$ at $400 \mathrm{mg} / \mathrm{ml}$. Similar to studies by Sadique et al. (1989), Olugbenga et al. (2005) and Malomo et al. (2011) suggested that the high membrane stabilizing activity of the extract of Celosia argentea which has potential to protect the erythrocyte membrane from free radical damage. The membrane stabilizing activity of the extract may be due to the presence of flavonoids, alkaloids, tannins and or saponins present in C. pictus and C. speciosus leaves. The extract yield for C. pictus was higher $(19.84 \%, \mathrm{w} / \mathrm{w})$ followed by C. speciosus (14.12\%, w/w) (Table 4).

Table 3. Membrane stabilization assay of crude extracts from Costus species.

\begin{tabular}{|c|c|c|c|}
\hline Extract & Concentration (mg/ml ) & O.D of Absorbance at $560 \mathrm{~nm}$ & $\%$ of inhibition \\
\hline \multirow[t]{4}{*}{ Costus pictus } & 100 & $0.25 \pm 0.26 *$ & $65.27 \%$ \\
\hline & 200 & $0.20 \pm 1.4$ & $72.22 \%$ \\
\hline & 300 & $0.18 \pm 0.41 * *$ & $75 \%$ \\
\hline & 400 & $0.12 \pm 0.35 * * *$ & $83.33 \%$ \\
\hline \multirow[t]{4}{*}{ Costus speciosus } & 100 & $0.36 \pm 0.71$ & $62.10 \%$ \\
\hline & 200 & $0.21 \pm 0.3^{* *}$ & $77.89 \%$ \\
\hline & 300 & $0.18 \pm 0.49$ & $81.05 \%$ \\
\hline & 400 & $0.11 \pm 0.18 * * *$ & $88.42 \%$ \\
\hline Diclofenac sodium (Positive control) & 400 & $0.2 \pm .42$ & $97.56 \%$ \\
\hline Negative control & 0 & $0.72 \pm 0.4$ & 0 \\
\hline
\end{tabular}

The above data represents the mean \pm SEM ( $=6$ ) Significant, $* p<0.05$, ** $p<0.01, * * * p<0.001$ when compared with Control using One way ANOVA followed by Dunnett's multiple " $t$ " test.

Table 4. Percentage yield of crude extract in Costus species.

\begin{tabular}{ll}
\hline Name of the plant & Yield of crude extract (w/w) \\
\hline Costus pictus & $19.84 \%$ \\
Costus speciosus & $14.12 \%$ \\
\hline
\end{tabular}

Phytochemical screening of the leaf extracts of Costus species revealed the presence of different phytochemicals, indeed phytochemical investigations of this plant have resulted in occurrences of alkaloids, phenols, tannins, steroids, anthracene, glycosides and flavonoids as reported by Ferosekhan et al. (2016). The bioactivity of plant products mainly depends on the amount of the major active constituents. The pharmacological activities of C. speciosus is mainly related to the phytochemical components which has been clearly indicated by Malabadi et al. (2016). Ferosekhan et al. (2016) reported the in vitro anti-hyperglycemic activity of $C$. speciosus and $C$. pictus in support of the traditional utility of these plant parts.

In conclusion, the data of our studies suggests that C. pictus and $C$. speciosus leaves extracts showed significant anti-inflammatory activity. Therefore our studies support the isolation and use of active constituents of these plants in treating inflammation.

\section{Conflict of interest statement}

Authors declare that they have no conflict of interest. 


\section{References}

Anson, M.L., Mirsky, A.E., 1932. The effect of denaturation on the viscosity of protein systems. Gen. Physiol. 15, 341350 .

Arya, D., Vidya, P., 2013. Comparative analysis of in vitro antiinflammatory and in vivo and in vitro antiarthritic activity in methanolic extract of Pluchea lanceolata Oliver \& Hiern. Int. J. Biol. Pharmaceut. Res. 4(9), 676680.

Chopra, R.N., Nayar, S.L., Chopra, I.C., 1956. Glossary of Indian Medicinal Plants. CSIR, New Delhi.

Cooper, E.L., 2004. Drug discovery, CAM and natural products. Evidence-Based Compl. Alt. Med. 1, 215-217.

Deshpande, V., Jadhav, V.M., Kadam, V.J., 2009. In vitro antiarthritic activity of Abutilon indicum L. J. Pharmaceut. Res. 2(4), 644-645.

Dev, S., 1997. Ethnotherapeutics and modern drug development: The potential of Ayurveda. Curr. Sci. 73, 909-928.

Ferosekhan, M., Ramu, A., Ravikumar, S., 2016. Scientific evaluation of traditionally known insulin plant Costus species for the treatment of diabetes in human. Int. J. Curr. Res. Biosci. Plant Biol. 3(6), 87-91.

Flower, R.J., Vane, J.R., 1974. Inhibition of prostaglandins synthesis. Biochem. Pharmacol. 23, 1439-1450.

Govindappa, M., Sadanada, T.S., Channabasava, R., Raghavender, V. B., 2010. In vitro anti-inflammatory, lipoxygenase, xanthin oxidase, xanthine activity of Tecoma stans (L.) Juss. ex Kunth. Int. J. Pharma Bio Sci. 2, 275-285.

Herman, C.J., Allen, P., Hunt, W.C., Prasad, A., Brady, T.J., 2004. Use of complementary therapies among primary care clinic patients with arthritis. Prev. Chronic Dis. 1, 12.

Kamboj, V.P., 2000. Herbal medicine. Curr. Sci. 78, 35-39.

Kokila, N., Radha, R., Jayshree, N., 2013. In vitro antioxidant and antiarthritic activity of polyherbal formulation. J. Pharmacogn. Herbal Formul. 13(3), 10-15.

McGaw, L. J., Jäger, A. K., van Stadenm, J., 1997. Prostaglandin synthesis inhibitory activity in Zulu, Xhosa and Sotho medicinal plants. Phytother. Res. 11(2), 113117.

Malabadi, R. B., Chalannavar, R. K., Meti, N. T., Gani, R. S., Vijayakumar, S., Mulgund, G. S., Masti, S., Chougale, R., Odhav, B., Sowmyashree, K., Supriya, S., Nityasree, B. R., Divakar, M. S., 2016. Insulin plant, Costus speciosus: Ethnobotany and pharmacological updates. Int. J. Curr. Res. Biosci. Plant Biol. 3(7), 151-161.
Malomo, S.O., Ore, A., Yakubu, M.T., 2011. In vitro and in vivo antioxidant activities of the aqueous extract of Celosia argentea leaves. Ind. J. Pharmacol. 43(3), 278-285.

Mizushima, Y., Kobayashi, M., 1968. Interaction of antiinflammatory drugs with serum proteins, especially with some biologically active proteins. J. Pharma Pharmacol. 20, 169-173.

Olugbenga, M., Fatunso, M.A., Makinde, J.M., 2005. Membrane stabilizing activity: a possible mechanism of action for the anti-inflammatory property of Gongronema latifolium leaves. Int. J. Biomed. Health Sci. 1(1), 1-4.

Perumal Samy, R., Pushparaj, P. N., Gopalakrishnakone, P., 2007. A compilation of bioactive compounds from Ayurveda. Bioinformation. 3, 100-110.

Rabe, T., Van Staden, J., 1997. Antibacterial activity of South African plants used for medicinal purposes. J. Ethnopharmacol. 56(1), 81-87.

Sadique, J., Chandra, T., Thenmozhi, V., Elango, V., 1989. The anti-inflammatory activity of Enicostemma littorale and Mollugo cerviana by carrageenan-induced inflammation and cotton pellet granuloma method in rats. Fitoterapia. 60, 525-532.

Sangita, C., Priyanka C., Protapaditya, D., Sanjib, B., 2012. Evaluation of in vitro anti-inflammatory activity of coffee against the denaturation of protein. Asian Pac. J. Trop. Biomed. S178-S180.

Sautebin, L., 2000. Prostaglandins and nitric oxide as molecular targets for anti-inflammatory therapy. Fitoterapia. 71, 48-57.

Singh, U.P., Srivsastava, B.P., Singh, K.P., Pandey, V.B., 1992. Antifungal activity of steroid saponins and sapogenins from Avena sativa and Costus speciosus. Naturalia Sao Paulo. 17, 71-77.

Sofowora, A., 1993. Screening plants for bioactive agents. In: Medicinal Plants and Traditional Medicine in Africa. Spectrum Books Ltd., Sunshine House, Ibadan, Nigeria. pp.134-156.

Trease, G.E., Evans, W.C., 2002. Pharmacology. $15^{\text {th }}$ Edn. Saunders Publishers, London.

Tsao, J.C.I., Zeltzer, L.K., 2005. Complementary and alternative medicine approaches for pediatric pain: a review of the state-of-the-science. Evidence-Based Compl. Alt. Med. 2(2), 149-159.

Vane, B.R., Boting, R. N., 1995. New insights into the mode of action of anti-inflammatory drugs. Inflamm. Res. 44, 110.

Warrier, P.K., Nambiar, V.P.K ., Ramankutty, C., 1994. Indian Medicinal Plants. Vol. 1-5. Orient Longman Ltd., Madras.

\section{How to cite this article:}

Ferosekhan, M., Ramu, A., Ravikumar, S., 2016. Anti-inflammatory activity of traditionally important insulin plant Costus species for the treatment of inflammation in human. Int. J. Curr. Res. Biosci. Plant Biol. 3(10), 144-149. doi: http://dx.doi.org/10.20546/ijcrbp.2016.310.017 